\title{
Ethics and Education: Curriculum Issues
}

\author{
Dennis Bialaszewski and Marsha Bialaszewski \\ Indiana State University, Terre Haute, IN, USA
}

\author{
D.Bialaszewski@att.net M.Bialaszewski@att.net
}

\begin{abstract}
Ethical considerations are a very important aspect for each one of us. However, faculty typically are often so concerned with covering all content associated within course structure they may not have sufficient time for class discussion regarding ethical considerations relevant for one's discipline. This is sometimes addressed by designing a specific course with a specific purpose being ethical considerations. For example one may see the existence of a "Business Ethics" course as a requirement for a business major. One of authors of this paper has designed an "Ethics and Information Systems" course offered as an elective in the MIS major. Issues such as downloading music without paying, ergonomic issues, issues of copyright, privacy issues, et cetera are covered through case studies. There is an examination of codes existing at the Midwestern university to cover ethical considerations related to computing. It is interesting to note that currently a student from this same Midwestern university is being sued for his file sharing practices.

Many texts in the IS area, such as Computer Ethics by Deborah Johnson, Computer Ethics and Social Values by Deborah Johnson and Helen Nissenbaum, Information Ethics for Librarians by Mark Alfino and Linda Pierce, A Gift of Fire: Social, Legal, and Ethical Issues in Computing by Sara Baase, and so forth, are being written and integrated in course curriculum. Moreover, many "Ethics Centers" are now existing, such as the Centre of Computing and Social Responsibility in England which addresses the social and ethical impacts of information and communication technologies through research, consultancy, and Education, the Online Ethics Center for Engineering and Science, the Software Engineering Ethics Research Institute, DePaul's Institute for Business and Professional Ethics, the Cyberspace Policy Institute, and so forth.
\end{abstract}

This increasing trend is not particular to the information systems/ computing areas only. Courses have been developed such as Ethics for Engineers, Ethics and Risk Management, Ethics in the Nursing Profession, et cetera. Many courses have been designed for the purpose of integrating ethical considerations into standard course content.

There are many ethical considerations to be discussed in the field of education itself. One author of this paper is an expert in the area of Educational Leadership and Administration. This author provides perspective on how these topics relate to education at various levels. This perspective is based on many years of experience. The considerations are not only for potential elementary and high school instructors but also for those teaching in higher education. Questions such as "what training have we been given in our doctoral preparation for class delivery and evaluation of students in various areas of higher education and is it an ethically responsible level of training” will

Material published as part of these proceedings, either on-line or in print, is copyrighted by Informing Science. Permission to make digital or paper copy of part or all of these works for personal or classroom use is granted without fee provided that the copies are not made or distributed for profit or commercial advantage AND that copies 1) bear this notice in full and 2) give the full citation on the first page. It is permissible to abstract these works so long as credit is given. To copy in all other cases or to republish or to post on a server or to redistribute to lists requires specific permission from the publisher at Publisher@InformingScience.org be discussed. The following are examples of actual excuses given at this Midwestern University during this last academic year: (1) I had to miss a week and the exam because I got married and went on a honeymoon, (2) my sister was murdered by the father of my sister's child and I must leave for another state to help her, (3) my 
father bought tickets some time ago for our family to go to Ireland and my father and I are going to run in a marathon there, (4) I was in a bad car accident last week and I had to miss all of last week, (5) my son was ill last week and I had to take him to a doctor, (6) The court finally made a decision and my husband and I are adopting our nephew and we must leave early Wednesday morning to pick up my nephew. I will be back in class on Monday.

Should all of these "excuses" be treated in the same manner. Some questions to reflect on are: Do doctoral programs sufficiently prepare doctoral candidates with ethical principles for responding to such excuses? Should universities have uniformity of policy in the treatment of such situations? The authors of this paper intend on surveying various doctoral programs in future research in order to determine the training that doctoral candidates are given for responding to such comments. There is anecdotal evidence existing of students failing a doctoral thesis defense because their results do not support the findings of their thesis chairperson. There is also evidence that this problem may be more likely to occur if it related to a grant for the dissertation chair. The authors will attempt to develop a survey to study this issue. A larger question is whether or not dissertation topics should be tied to grants.

Issues such as: Does zero tolerance make any sense? How much documentation should one be required to expect. In the case of the murdered sister the student brought in a newspaper obituary and also the church program from the funeral service. This was not asked for by the author. How much discussion should take place at the university level for handling such cases is an important issue. Should this discussion just be left up to each individual faculty member and does that lead to an inconsistent treatment of students? In this paper we will review the ethical principal of "universality” keeping in mind the principal of treating all students the same.

In practice treating all the same is sometimes very difficult to do. A situation recently arose when a student who had been doing well in class (we'll call him "Fred") was recently fired from a group project. A student getting fired in that class receives zero credit and is NOT placed on another group. In this class the instructor offers to pre-grade projects up to 48 hours prior to the actual time the project is due. However, no feedback is given 48 hours or less prior to the due date. Projects are structured so they can be scaled down into 3 parts. If one is fired the remaining two students are only held responsible for 2 of the parts and do not complete the work of the fired member. The fired member said "Hey ...I did some work ... it was not due yet ... I was going to finish my part " The others on the group who had not been great students said " we are concerned about our grade ... we needed feedback from our teacher about what we are going to turn in ... we wanted hin to pre-grade it ... we were not willing to gamble that you would turn in your work at the last minute and it would all be quality work.” The students had copies of e-mails where deadlines were given and the fired student never did comply with the deadlines. They had the documentation. The faculty member agreed with the firing as all rules were met even though he knew that the fired student had offered much in class and prior work was good work. In our practices do we really attempt to treat all the same or do we show favoritism.

Faculty have mentioned that they tend to be prejudiced and favorable towards the student who starts off the semester doing very well in class. The step daughter of one of the authors boasted that as a college student she always tried to start off doing well because then she believed she could take more liberties than other students during the semester such as missing more classes. If college faculty do act in that manner is this ethical treatment?

Do elementary school teachers and high school teachers favor the student who starts off the semester doing well? Do elementary and high school teachers have prejudiced views based on gossip prior to students joining their classrooms? What training do they have for this? The authors of this paper suggest case studies of various situations that actually occur should be regular classroom exercises. These authors present an argument for incorporating such case studies as an integral part for someone receiving an undergraduate degree in education. This can be done by including such a case study in several courses or perhaps developing an "Ethics in Education" 
course. In this paper within higher education we reflect on how university faculty have been trained to handle student behavior and assessment if their major was not offered through a school of education? Should these consideration be a discussion for faculty in the various colleges? The authors will present their viewpoints based on a combined more than 30 years of teaching.

As was mentioned previously, courses in many disciplines are being developed to focus on ethical issues within the discipline. The authors will provide their experience with such courses and their perspective as to whether this is an area in which we should be devoting more effort. It is the strong belief of these authors that this presentation will generate much discussion at the conference and in the future generate much needed research.

\section{Biographies}

Dennis Bialaszewski has more than 30 years experience in higher education. He is a past recipient of the New York State Chancellor's Award for Excellence in teaching (1976), The Exemplary Professional Productivity Award (1992) based upon research productivity over a 5 year span, and also the Exemplary Service Award (2003) based on service contributions to the university (Indiana State), the profession, and the community. Prior to joining Indiana State he was a tenured faculty member of Mississippi State University where he also served on several doctoral committees.

Marsha Bialaszewski has more than 30 years of teaching experience. She has served on Special Education Advisory Boards for both Indiana State University and also St. Mary of the Woods College. She has recently completed her doctorate in Educational Leadership from Indiana State University. While in the doctoral program she has been a 2 time recipient of the prestigious $\mathrm{J}$. Edgar Morfett award for research productivity. Her primary area of expertise is in the area of Facilitated Individualized Education Programs. 